\title{
Embracing metaliteracy Metamodern libraries and virtual learning communities
}

A recent book, Metamodernism and Changing Literacy, by Valerie J. Hill focuses on the intersection of the current philosophical moment by exploring the concept of metamodernism through the lens of metaliteracy. As argued in the book, "Only through metaliteracy can we become digital citizens who seek to acquire, produce and share knowledge in metamodern culture." In Notes on Metamodernism, Timotheus Vermeulen and Robin van den Akker coin the term metamodernism and argue that it is a discourse based on "recent developments in architecture, art, and film" that oscillates "between a modern enthusiasm and a postmodern irony." ${ }^{2}$ The Notes on Metamodernism webzine features essays on metamodern art and architecture, music and fashion, film and TV, as well as networked culture and politics. ${ }^{3}$

These uncertain times demonstrate the need for defining a shared philosophy about this moment that is grounded in mindful praxis. During the COVID-19 global pandemic, for instance, educators and learners shifted quickly to online platforms to teach and to learn. This immediate transition to technology-mediated spaces exposed fissures in levels of preparedness and access while illuminating a common purpose to better understand the virtual dimension of literacy and learning. The revolutionary changes brought forth by digital culture and social information environments have been accelerated by this global shift to online.

These fundamental changes within the context of a global pandemic require a reimagining of our pedagogical strategies to prepare learn- ers at all age levels to be active and reflective digital citizens.

\section{The ACRL Framework and metaliteracy}

The ACRL Framework for Information Literacy for Higher Education envisions the learner as an ethical producer of information in participatory learning communities. ${ }^{4}$ As a conceptual model, the ACRL Framework combines several influences to recast information literacy through six frames of learning and related dispositions and knowledge practices. Metaliteracy influenced the ACRL Framework by defining the learner as a reflective and active producer of content in collaborative information environments. Although the metacognitive domain of metaliteracy was ultimately diminished in the final draft of the ACRL Framework, reflection is still a key part of the revised definition of information literacy and related frames. ${ }^{5}$

As originally conceived, "Metaliteracy promotes critical thinking and collaboration in a digital age, providing a comprehensive framework to effectively participate in social

Valerie J. Hill is director of the Community Virtual Library, a project of New Media Arts and teaches part-time multi-media courses at Peninsula College in Washington, email: vhilledu@gmail.com, Thomas P. Mackey is professor in the Department of Arts and Media, School of Arts and Humanities at SUNY Empire State College, email: tom.mackey@esc.edu

(c) 2021 Valerie J. Hill and Thomas P. Mackey 
media and online communities." ${ }^{6}$ Metaliterate learners create responsible content in social settings, including virtual communities. The metaliteracy framework emphasizes several active metaliterate learner roles and four domains of learning, including the affective (feeling), behavioral (acting), cognitive (thinking), and metacognitive (reflecting). As part of this unified model, metaliteracy integrates several characteristics that prepare learners to be informed, adaptable, collaborative, and civic-minded in learning communities. The roles, domains, and characteristics are all reinforced through a comprehensive set of metaliteracy goals and learning objectives. ${ }^{7}$

\section{Metamodernism and metaliteracy}

As the world advanced into the modern era during the industrial revolution, tremendous physical change took place with inventions for travel, communication, and modern conveniences giving individuals more time for thought processes. As technologies advanced with the emergence of virtual media, through film, advertising, and television, opportunities to pause and reflect started to diminish. By the mid-20th century, postmodernism brought forth the rejection of realism alongside the deconstruction of grand narratives and belief systems. Filled with irony and "anti-realism," postmodernism questioned objectivism, absolute knowledge, and truth. ${ }^{8}$

Since the launch of the Internet and the turn of the 21 st century, a new "sense of feeling" has been brewing, a way of combining the best of both tradition and innovation-metamodernism. ${ }^{9}$ This metamodern moment can be viewed as an oscillation between various ideas that seem to be opposing, such as traditions from the historical past and revolutionary changes in the future. Metamodernism allows room for both irony and sincerity, reason and faith. The blending of both physical and virtual worlds defines a metamodern phenomenon in which metaliteracy has become essential for life and learning in real and virtual spaces.

The impact of the Internet and networked culture on literacy and learning has been significant. For the past two decades, much has been written and discussed about the topic of disruptive technologies in education, ${ }^{10}$ especially as the term disruptive has become a metaphor for our times. Educators and learners in all fields and all ages are faced with a proliferation of technology tools, online learning platforms, new media formats, and millions of apps. Practitioners are keenly aware of the vast amounts of information inundating learners daily from a multitude of sources.

In social information environments that lack traditional editorial filters, misinformation and disinformation permeate virtual spaces unchecked. Proprietary platforms claim neutrality in the face of blatant untruths and have only recently started to flag or take down harmful misinformation during the coronavirus pandemic. ${ }^{11}$

As educators strive to deal with this information flood in a world of partisan politics and questionable content, critical and reflective thinking are required to better understand this philosophical moment and one's role in it. Metaliteracy promotes the development of metaliterate digital citizens who are civic-minded and effectively produce content in a participatory networked culture. Since metamodernism "articulates itself by means of diverse practices," it opens the door for inclusive insights that align with the overall goals of metaliteracy to cross boundaries and build collaborative communities.

\section{Embedding metaliteracy in libraries and virtual communities}

Only a few years ago it was unimaginable that learners could carry libraries in their pockets on digital devices. Today, most documents are borndigital, and are accessed through public and academic libraries on smart devices to find materials in numerous formats. Instant access has become an expectation. However, alongside that convenience is the responsibility to evaluate an exponential amount of information. A quick Google search for the term online learning, for instance, brings 2 billion hits in seconds. Teaching learners how to critically evaluate online information is far from easy, as many people think an Internet search alone is research. 
The first goal of metaliteracy addresses the critical need to "Actively evaluate content while also evaluating one's own biases," which expands beyond the search itself to focus on how individuals analyze information and their own preconceptions. A library has always been a place to access highquality content and to learn about literacy.

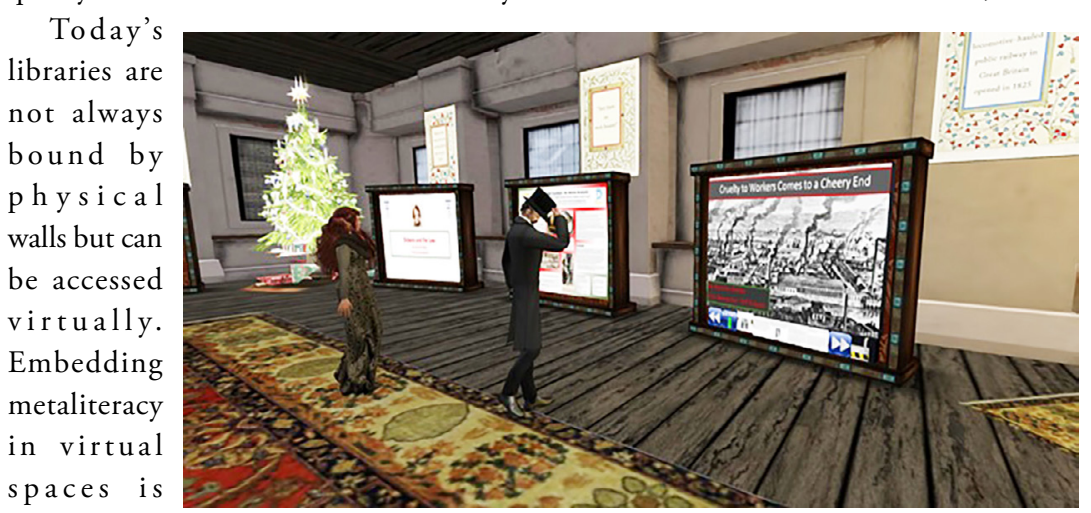

challenging, Tour of the Dickens Project, Community Virtual Library. in Education), VCARA (San Jose State University's iSchool project), and many colleagues and universities to embed the core components of metaliteracy into virtual world simulations for immersive learning. By taking on metaliterate learner roles such as producer, translator, and even teacher in these virtual environments, learners strive toward but librarians

are finding ways to do just that.

The Community Virtual Library (CVL) has offered programs with a focus on information literacy for the ACRL Virtual World Interest Group monthly for over a decade in the virtual world of Second Life. ${ }^{12}$ In addition, CVL has built a 3D Digital Citizenship Museum in the virtual world of Kitely, which houses numerous rooms on metaliteracy concepts and topics such as cybersecurity, digital legacy, privacy, digital archival and more. Advocating respect for intellectual property in virtual spaces is a goal of CVL, which aligns to the second goal of metaliteracy to "Engage with all intellectual property ethically and responsibly." Promoting authenticity in simulated spaces exemplifies the role-playing aspect of metaliteracy while responsibly engaging with virtual content. The annual Dickens Project, for instance, brings A Christmas Carol to life with Victorian-era London, live readings of Dickens, and a historical simulation where participants dress in authentic attire from the period.

Numerous educational communities collaborate in virtual worlds to create and distribute information, which is the third goal of metaliteracy, to "Produce and share information in collaborative and participatory environments." CVL partners with ISTE (International Society for Technology the fourth goal of metaliteracy, to "Develop learning strategies to meet lifelong person a l and professional goals." Learners take charge of their development in these virtual spaces and prepare themselves for further growth as scholars and professionals in the field.

\section{Metamodern learners as digital citizens}

Whether today's connected yet divided society embraces the term metamodernism or not, learners live in networked digital culture and are challenged to become effective digital citizens. A metamodern learner is always striving toward that fourth goal of metaliteracy, which emphasizes that learning is a lifelong process. This metamodern age exemplifies the oscillation between the best practices of the past and a willingness to change and adapt to the future. Deep learning and critical thinking require the pursuit of knowledge and understanding through inquiry and research balanced with flexibility and adaptation to a changing information environment.

Perhaps the most important idea to instill in learners is that digital citizenship is a personal responsibility. Prior to the Internet, the information hierarchy was linear, and individuals learned through mastery of knowledge and skills that were developed through a fairly fixed curriculum. Professional gatekeepers guaranteed reliable and verifiable information that 
was primarily in print and then expanded to digital formats.

Digital culture has toppled the hierarchy of information, leaving everyone overwhelmed by the sheer volume of content in various forms needing evaluation. Even more concerning might be the need to produce information in a multitude of digital formats. This shift from traditional editorial filters to de-centered digital environments, where everyone thinks they are an expert, requires a higher level of individual and civic responsibility to create and share information ethically.

\section{Conclusion}

Embedding metaliteracy into studies across multiple disciplines is a challenge for educators in classrooms, libraries, and online. Advancing metaliterate learning in the daily lives of people throughout their lifespan may also seem daunting. At the same time, the collaborative dimension of metaliteracy supports a shared role between faculty and librarians and among learners who start to see themselves as teachers. The ACRL Framework offers harmonizing themes for developing reflective and ethical producers of information as well. Advancing metacognitive reflection on thinking processes has long been touted by educators as imperative to deep learning and inquiry.

With the rapidly changing information environments that continue to emerge in digital culture, it is time to advocate for and embrace metaliteracy as a pedagogical paradigm that supports reflective and active learning in metamodern libraries and virtual learning communities.

\section{Acknowledgement}

Thank you to Trudi E. Jacobson, head of the information literacy department at the University at Albany-State University of New York, for providing thoughtful feedback.

\section{Notes}

1. V. J. Hill, Metamodernism and Changing Literacy: Emerging Research and Opportunities
(Hershey, PA: IGI Global, 2020), 252.

2. T. Vermeulen and R. van den Akker, "Notes on metamodernism," Journal of Aesthetics \& Culture (2010) 2(1), 1, https://doi:10.3402 /jac.v2i0.5677.

3. "Notes on Metamodernism," accessed August 11, 2020, http://www.metamodernism.com/.

4. ACRL, last modified January 11, 2016, "Framework for Information Literacy for Higher Education," http://www.ala.org/acrl/standards /ilframework.

5. Diane Fulkerson, Susan Ariew, and Trudi Jacobson, "Revisiting Metacognition and Metaliteracy in the ACRL Framework," Comminfolit 11, no. 1 (2017): 21, https://doi.org/10.15760 /comminfolit.2017.11.1.45.

6. Mackey, T., and Jacobson, T. "Reframing Information Literacy as a Metaliteracy," College \& Research Libraries, 72, no. 1 (2011), 62-78. https://doi.org/10.5860/crl-76r1.

7. T. Jacobson, T. Mackey, K. O’Brien, M. Forte, and E. O'Keefe, "2018 Metaliteracy Goals and Learning Objectives," Metaliteracy.org, June 4, 2020, https://metaliteracy.org/learning -objectives/2018-metaliteracy-goals-and-learning -objectives/.

8. S. R. C. Hicks, Explaining postmodernism: Skepticism and socialism from Rousseau to Foucault (Belair, CA: Scholargy Publishing, 2004).

9. L. Turner, "Metamodernist Manifesto" (2011), http://www.metamodernism.org/ (accessed August 3, 2020).

10. Joseph L. Bower and Clayton M. Christensen, "Disruptive Technologies: Catching the Wave Harvard Business Review (January-February 1995), 43-53," Journal of Product Innovation Management 13, no. 1 (1996): 75-76, https://doi. org/10.1016/0737-6782(96)81091-5.

11. C. Kang and S. Frenkel, "Facebook Removes Trump Campaign's Misleading Coronavirus Video" New York Times, https://nyti.ms/3i9cLVx.

12. CVL, Digital Citizenship Museum in Kitely, Community Virtual Library, New Media Arts, Inc. https://communityvirtuallibrary.org/ digital-citizenship-museum/ (accessed August 5, 2020). $z$ 